\title{
Characterization of Biomphalaria orbignyi, Biomphalaria peregrina and Biomphalaria oligoza by Polymerase Chain Reaction and Restriction Enzyme Digestion of the Internal Transcribed Spacer Region of the RNA Ribosomal Gene
}

\author{
Linus Spatz, Teofânia HDA Vidigal****, Márcia CA Silva**, \\ Stella Maris Gonzalez Cappa, Omar S Carvalho*/+
}

\begin{abstract}
Departamento de Microbiología, Facultad de Medicina, Universidad de Buenos Aires, Buenos Aires, Argentina *Centro de Pesquisas René Rachou-Fiocruz, Av. Augusto de Lima 1715, 30190-002 Belo Horizonte, MG, Brasil

**Departamento de Zoologia, Universidade Federal de Minas Gerais, Belo Horizonte, MG, Brasil
\end{abstract}

The correct identification of Biomphalaria oligoza, B. orbignyi and $\mathrm{B}$. peregrina species is difficult due to the morphological similarities among them. B. peregrina is widely distributed in South America and is considered a potential intermediate host of Schistosoma mansoni. We have reported the use of the polymerase chain reaction and restriction fragment length polymorphism analysis of the internal transcribed spacer region of the ribosomal DNA for the molecular identification of these snails. The snails were obtained from different localities of Argentina, Brazil and Uruguay.

The restriction patterns obtained with MvaI enzyme presented the best profile to identify the three species. The profiles obtained with all enzymes were used to estimate genetic similarities among B. oligoza, B. peregrina and B. orbignyi. This is also the first report of B. orbignyi in Uruguay.

Key words: Biomphalaria orbignyi - Biomphalaria peregrina - Biomphalaria oligoza - snails - ribosomal DNA - internal transcribed spacer - polymerase chain reaction

Biomphalaria snails are present in several countries of America and Africa, and some species serve as intermediate hosts for the trematode Schistosoma mansoni. In Brazil, ten species and one subspecies of Biomphalaria are known. However, only three species are naturally infected with $S$. mansoni: $B$. glabrata (Say, 1818), B. tenagophila (Orbigny, 1835 ) and B. straminea (Dunker, 1848) while $B$. peregrina (Orbignyi, 1835) and $B$. amazonica Paraense, 1966, based on experimental infection, are considered potential hosts of the parasite (Corrêa \& Paraense 1971, Paraense \& Corrêa 1973). In Argentina and Uruguay there are no reported cases of schistosomiasis mansoni. However, the presence of $B$. tenagophila, B. straminea, and B. peregrina in these countries (Paraense 1966, 1970), the continuous extension of schistosomiasis mansoni to southernmost Brazil (Paraense 1987), the recent finding of B. glabrata in Rio

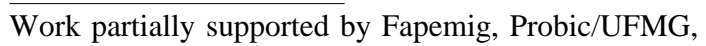
Ubacyt and Foncyt.

Corresponding author. Fax: + 55-31-295.3115. E-mail: omar@cpqrr.fiocruz.br

Received 27 October 1999

Accepted 19 June 2000
}

Grande do Sul (Carvalho et al. 1998), and the first detection of a focus of schistosomiasis in the same state (Graeff-Teixera et al. 1999) suggest the possibility of expansion of the disease from Brazil to the neighbour southern countries.

The extensive intraspecific variation of the morphological characteristics commonly used for identifying freshwater snails of medical importance, greatly complicates the classical identification (Paraense 1975a). B. orbignyi Paraense, 1975 cannot be differentiated from $B$. peregrina neither by shell characteristics nor by the morphology of certain genital organs and has also been considered as a variety of $B$. peregrina by Orbigny (1837), as mentioned by Paraense (1975b). This species was originally described in 25 localities from Argentina and was described as refractary to $S$. mansoni infection (Paraense 1975b). It was also reported in Cuba by Yong and Perera (1989). Yong et al. (1991, 1995) and Yong and Perera (1989) reported that $B$. orbignyi is very similar to $B$. havanensis and isoenzymatic techniques were used as auxiliary tools to identify these snails. However, B. havanensis has been considered a potential intermediate host of S. mansoni (Richards 1963, Malek 1985).

$B$. peregrina is one of the most widespread planorbid species in the neotropical region (Paraense 1966, 1975a). Paraense and Deslandes 
(1957) reported that $B$. havanensis (mentioned as Taphius maya) is indistinguishable from $B$. peregrina by shell characteristics.

Later, Paraense and Deslandes (1958a) and Paraense (1966) discussed the morphological relations between these species.

B. oligoza Paraense, 1974 was studied by Paraense and Deslandes (1958b) as Tropicorbis philippianus and was found in four Brazilian states (Mato Grosso, Paraná type locality, Santa Catarina and Rio Grande do Sul) and in Córdoba Province, Argentina. This species is resistant to $S$. mansoni infection (Paraense pers. commun.). Paraense (1974) stated that Brazilian specimens were incorrectly identified as Planorbis philippianus Dunker, 1848 , (synonym of $B$. peregrina), and compared $B$. oligoza with $B$. orbignyi showing that these species can be distinguished only by some morphological characteristics (Paraense 1975b).

The polymerase chain reaction and restriction fragment length polymorphism (PCR-RFLP) analysis of the internal transcribed spacer (ITS) region of the rDNA has been used for species identification in snails of the genus Oncomelania and Bulinus (Hope \& McManus 1994, Stothard et al. 1996, Stothard \& Rollinson 1997). In previous studies, we have shown PCR-RFLP as a potential tool to identify several Biomphalaria species from Brazil and other regions from South America (Vidigal et al. 1998, 2000, Caldeira et al. 1998, 2000, Spatz et al. 1999). In the present work, we report the use of this technique for specific identification of B. oligoza, B. peregrina and B. orbignyi from different localities of Brazil, Argentina and Uruguay. We have also used restriction profiles to estimate genetic similarities among these species.

\section{MATERIALS AND METHODS}

Snail samples and morphological identification - The studies were undertaken using samples of field populations from Argentina, Brazil and Uruguay (Table). Ten specimens of each population were killed and fixed (Deslandes 1951, Paraense 1976). Before fixing the specimens, their foot was removed for subsequent DNA extraction. Fixed specimens were identified by means of comparative morphology of the reproductive organs and shells, according to Paraense and Deslandes (1958a), and Paraense (1974, 1975a, b). In addition, snails identified as B. havanensis (Pfeiffer, 1839), obtained from three different localities in Cuba and maintained in the Departamento de Malacología, Instituto Pedro Kouri, Havana, Cuba, were included in this study.

DNA extraction - Total DNA was extracted from the foot of each snail using the Wizard Genomic DNA Purification Kit (Promega) as de- scribed by Vidigal et al. (2000).

PCR-RFLP analysis - The entire ITS (which includes the 5.8S rDNA gene together with the flanking ITS1 and ITS2 spacers) was amplified using the primers ETTS2 (5-TAACAAGGTTT CCGTAGGTGAA-3) and ETTS1 (5-TGCTTAA GTTCAGCGGGT-3) (Kane \& Rollinson 1994). The PCR amplification conditions were the same as used by Vidigal et al. (1998). Several enzymes used in our previous studies with Biomphalaria snails (Vidigal et al. 1998, 2000, Caldeira et al. 1998, 2000, Spatz et al. 1999) were tested: AluI, (New England Biolabs, USA), DdeI, HaeIII, RsaI, Hap II (Promega) and MvaI (Boehringer Mannheim). Digestion and RFLP analysis were performed as described by Vidigal et al. (1998). The localities and number of specimens used for the molecular analysis are shown in the Table.

Quantitative analysis of the restriction profiles - The bands observed in each lane of the gels, produced with the six enzymes, were compared with all the other lanes of the same gel. A matrix of taxon/character were constructed on the basis of presence/absence of each band, where only easily visible bands were scored and minor less intensely staining bands were ignored. The percentage of shared bands was calculated using the Similarity Coefficient of Dice (Dice 1945) and NTSYS-PC program, Version 2.0 (Rohlf 1992). These data were clustered with UPGMA, Unweighted Pair Group Method Analysis (Sneath \& Sokal 1962) and used for the construction of the phenetic tree. The comparison was made among individual snails of the same species from different localities and among snails from different species. The average similarity among all the individuals was calculated and marked on the tree as the phenon line. Divergence below the phenon line indicates separation of distinct groups. The genetic distance was calculated using the coefficient of Nei and Li (1979) and Treecon for Windows program (Version 1.2, Van de Peer \& De Wachter 1994). These data were clustered with UPGMA and Neighbour-joining, NJ (Saitou \& Nei 1987, Studier \& Keppler 1988) and used for the construction of genetic distance trees. The reliability of the UPGMA and NJ distance trees were assessed by the bootstrap method (Felsenstein $1985)$ with 1,000 pseudoreplications. Only bootstrap values higher than $70 \%$ were considered significant (Hillis \& Huelsenbeck 1992) and values higher than $50 \%$ were shown in the trees.

\section{RESULTS}

Morphological identification of the snail populations - Results of morphological identifications of the snails are shown in the Table. B. orbignyi is reported for the first time in Uruguay. 
TABLE

Species, localities, geographical coordinates and abbreviations of the Biomphalaria populations used

\begin{tabular}{|c|c|c|c|c|}
\hline Species & $\begin{array}{c}\text { No. of } \\
\text { specimens }\end{array}$ & Localities & $\begin{array}{c}\text { Geographical } \\
\text { coordinates }\end{array}$ & Abbreviation \\
\hline B. orbignyi & $\begin{array}{l}6 \\
2 \\
4 \\
4 \\
4 \\
4\end{array}$ & $\begin{array}{l}\text { San Roque, Corrientes Province, AR } \\
\text { Termas, Arapey, URU } \\
\text { Sierra Quijadas, San Luis Province, AR } \\
\text { La Carlota, Cordoba Province, AR } \\
\text { Chamical, La Rioja Province, AR } \\
\text { Patquia, La Rioja Province, AR }\end{array}$ & $\begin{array}{l}28 \mathrm{~s} 34 / 58 w 43 \\
30 \mathrm{~s} 58 / 57 w 32 \\
31 \mathrm{~s} 30 / 68 w 30 \\
33 \mathrm{~s} 26 / 63 w 18 \\
30 \mathrm{~s} 21 / 66 w 19 \\
30 \mathrm{~s} 35 / 66 w 53\end{array}$ & $\begin{array}{l}\text { BorCOAR1 to } 6 \\
\text { BorARAURU1 and } 2 \\
\text { BorSLAR } 1 \text { to } 4 \\
\text { BorCOBAR } 1 \text { to } 4 \\
\text { BorCHRIAR } 1 \text { to } 3 \\
\text { BorPARIAR1 to } 4\end{array}$ \\
\hline Total & 24 & 6 & & \\
\hline B. peregrina & $\begin{array}{l}2 \\
1 \\
2 \\
2 \\
2 \\
2\end{array}$ & $\begin{array}{l}\text { Alfenas, MG, BR } \\
\text { Bom Jesus da Penha, MG, BR } \\
\text { Buenos Aires Province, AR } \\
\text { Córdoba Province, AR } \\
\text { Cholila, Chubut Province, AR } \\
\text { Paso de Los Toros, URU }\end{array}$ & $\begin{array}{l}21 \mathrm{~s} 25 / 45 w 56 \\
21 \mathrm{~s} 01 / 46 w 31 \\
34 \mathrm{~s} 36 / 58 w 27 \\
31 \mathrm{~s} 25 / 64 w 10 \\
42 \mathrm{~s} 31 / 71 w 27 \\
32 \mathrm{~s} 49 / 56 \mathrm{w} 31\end{array}$ & $\begin{array}{l}\text { BprMGBR } 1 \text { and } 2 \\
\text { BprBMGBR1 } \\
\text { BprBAAR } 1 \text { and } 2 \\
\text { BprCoBAR } 1 \text { and } 2 \\
\text { BprCHUAR1 and } 2 \\
\text { BprPTURU1 and } 2\end{array}$ \\
\hline Total & 11 & 6 & & \\
\hline B. oligoza & $\begin{array}{l}2 \\
2 \\
4\end{array}$ & $\begin{array}{l}\text { Eldorado do Sul, RS, BR } \\
\text { Florianópolis, SC, BR } \\
\text { Córdoba Province, AR }\end{array}$ & $\begin{array}{l}30 \mathrm{~s} 05 / 51 \mathrm{w} 36 \\
27 \mathrm{~s} 35 / 48 \mathrm{w} 32 \\
31 \mathrm{~s} 19 / 65 \mathrm{w} 05 \\
\end{array}$ & $\begin{array}{l}\text { BolRSBR } 1 \text { and } 2 \\
\text { BolSCBR1 and } 2 \\
\text { BolCOBAR } 1 \text { to } 4\end{array}$ \\
\hline Total & 8 & 3 & & \\
\hline
\end{tabular}

AR: Argentina; BR: Brazil; URU: Uruguay

Restriction profile analysis - After morphological identification, snails were submitted to molecular analysis. The PCR amplification of the Biomphalaria ITS region with the primers ETTS2 and ETTS1 resulted in a product of approximately $1 \mathrm{~kb}$ for B. oligoza and B. peregrina (Vidigal et al. 2000 ) and $1.3 \mathrm{~kb}$ for B. orbignyi (data not shown). Fig. 1 shows the rDNA ITS restriction profiles of representative specimens of $B$. peregrina from Brazil (lanes 1 to 3), Argentina (lanes 4 and 5, 8 to 11), and Uruguay (lanes 6 and 7); B. oligoza from Brazil (lanes 12 to 15 ) and Argentina (lanes 16 to 19); and B. orbignyi from Argentina (lanes 20 to 42), produced by the digestion with $M v a \mathrm{I}$ (Fig. 1A), Hae III (Fig. 1B), which exhibit the most promising profiles for specific identification of the three species. The $M v a \mathrm{I}$ produced two distinct profiles for $B$. peregrina and $B$. oligoza snails. The profiles showed two clear fragments for $B$. peregrina and $B$. oligoza, although some polymporhism can be observed (lanes 6, 7,9). These profiles exhibit (a) one fragment of $700 \mathrm{bp}$ approximately, shared among $B$. peregrina and B. oligoza specimens; (b) one fragment of approximately $300 \mathrm{bp}$ (P1) for $B$. peregrina snails; and (c) one fragment for $B$. oligoza of $200 \mathrm{bp}$ approximately (O1). However, this enzyme produced two polimorphic profiles for B. orbignyi specimens (profile 1: lanes 20 to 35 ; profile 2: lanes 36 to 42 ). The profiles produced with HaeIII (Fig. 1B) were more complex than those produced with $M v a \mathrm{I}$ and also showed polymorphism among the $B$. peregrina snails (lanes 1 to 11). Although the profiles obtained for $B$. peregrina snails from Brazil, Argentina and Uruguay were distinct, two bands (120 bp, approximately) were shared among all B. peregrina specimens. HaeIII produced a clear species-specific pattern for B. oligoza (lanes 12 to 19) with six fragments (two of them are species-specific, see arrows in the Fig. 1B). For B. orbignyi (lanes 20 to 42), the HaeIII profiles showed some polymorphism, but at least five fragments were shared among all snails belonging to this species.

By the analysis of the profiles obtained with HpaII enzyme (data not shown) three points can be noted: (a) profiles for $B$. peregrina from Córdoba and B. oligoza were similar; (b) the other $B$. peregrina showed some polymorphic bands and some bands shared by B. oligoza. However, one fragment of approximately $290 \mathrm{bp}$ was shared among most of $B$. peregrina specimens (except the specimens from Córdoba); and (c) this enzyme allowed the separation of $B$. orbignyi from $B$. oligoza and $B$. peregrina, although some interpopulational polymorphism was observed.

The enzyme $A l u \mathrm{I}$ (data not shown) showed similar profiles for B. peregrina and B. oligoza and some polymorphism for B. peregrina. Due to 
the similarity of the profiles between $B$. peregrina and $B$. oligoza, it was not possible to separate these two species using this enzyme. However, $B$. peregrina snails from Brazil showed one exclusive band of approximately $200 \mathrm{bp}$, which allowed the separation of these specimens from $B$. oligoza. For $B$. orbignyi this enzyme produced a profile that, in spite of its complexity, allowed the separation of this species from $B$. peregrina and $B$. oligoza.

A

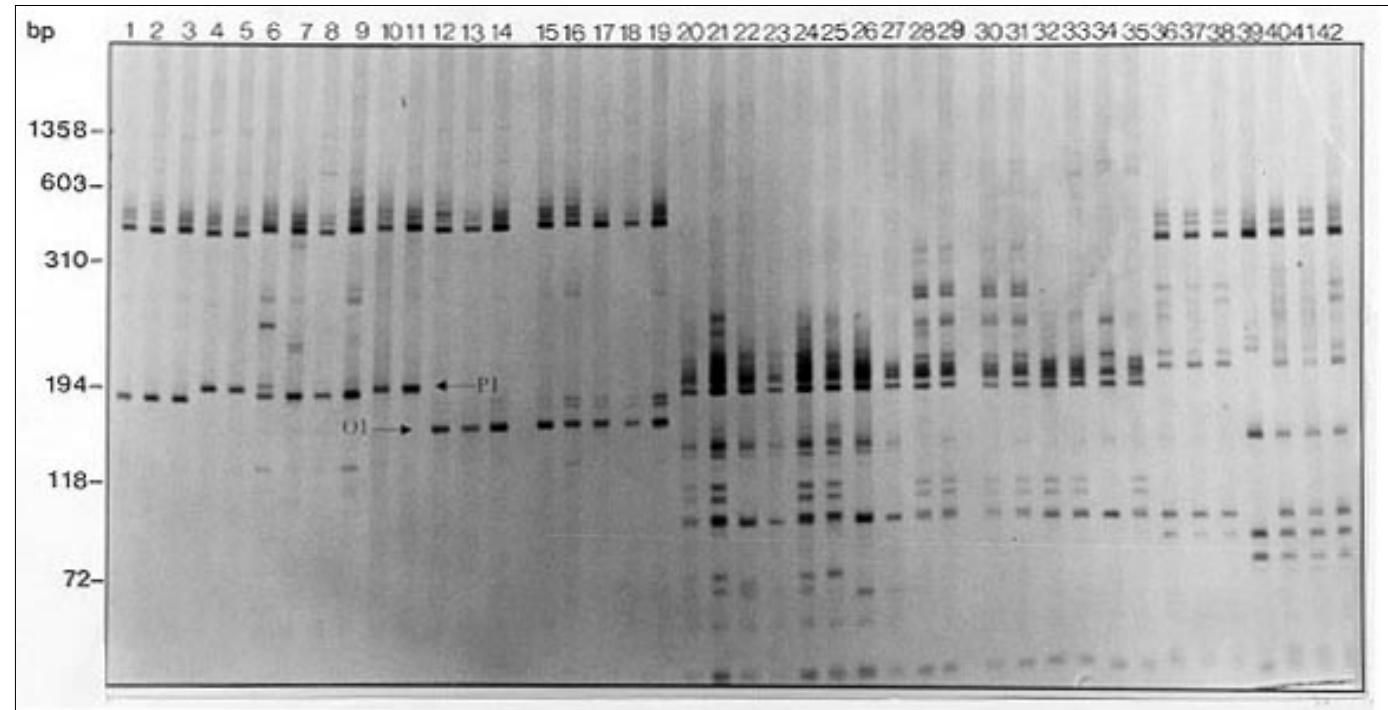

B

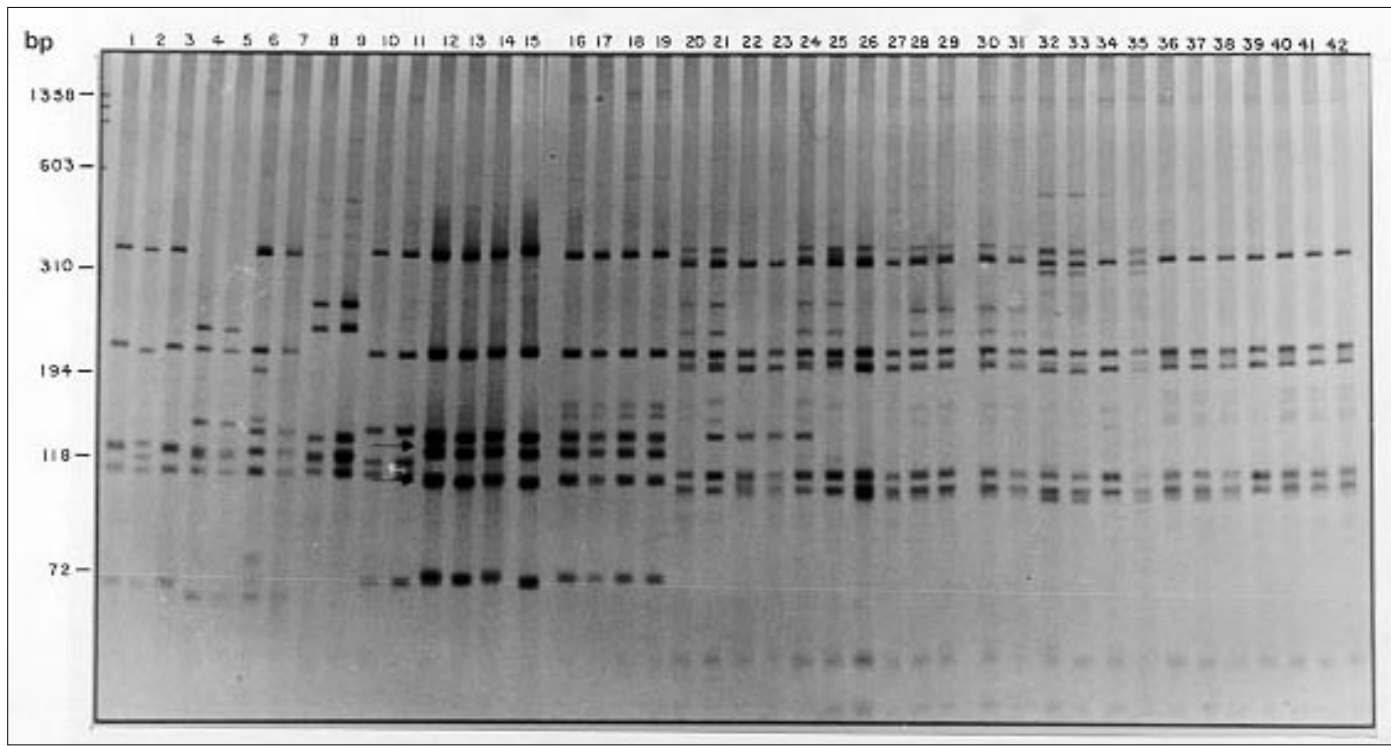

Fig. 1: silver stained polyacrylamide gels $6 \%$ showing the polymerase chain reaction and restriction fragment length polymorphism profiles obtained following the digestion of the rDNA internal transcribed spacer with (A) MvaI; (B) HaeIII. Lane 1: Biomphalaria peregrina from Alfenas, MG, Brazil; lane 2: B peregrina from Bom Jesus da Penha, MG, Brazil; lane 3: $B$. peregrina, from Alfenas, MG, Brazil; lanes 4-5: B. peregrina from Buenos Aires, Argentina; lanes 6-7: B. peregrina from Paso de los Toros, Uruguay; lanes 8-9: B. peregrina from Cholila, Argentina; lanes 10-11: B. peregrina from Córdoba Province, Argentina; lanes 12-13: B. oligoza from Florianópolis, SC, Brazil; lanes 14-15: B. oligoza from Eldorado do Sul, RS, Brazil; lanes 16-19: B. oligoza from Córdoba Province, Argentina; lanes 20-25: B. orbignyi from San Roque Corrientes Province, Argentina; lanes 26-27: B. orbignyi Termas, Arapey, Uruguay; lanes 28-31: B. orbignyi Sierra Quijadas, San Luis Province, Argentina; lanes 32-34: B. orbignyi La Carlota, Córdoba Province, Argentina; lanes 35-38: B. orbignyi from Chamical, La Rioja Province, Argentina; lanes 39-42: B. orbignyi from Patquia, La Rioja Province, Argentina. Molecular size markers are shown on the left of each gel. The arrows on the $M v a \mathrm{I}$ figure indicate species-specific fragments of $B$. oligoza $(\mathrm{O} 1)$ and $B$. peregrina $(\mathrm{P} 1)$, The arrows on the HaeIII figure indicate species-specific fragments of B. oligoza. 
The enzymes DdeI and RsaI (data not shown) did not permit a clear identification of the three species either because of very similar profiles between B. peregrina and B. oligoza or extensive intraspecific polymorphism presented by $B$. peregrina.

As the best results were obtained with $M v a \mathrm{I}$, this enzyme was also tested in order to separate $B$. havanensis from the species studied here. Fig. 2 shows the comparison among $M v a$ I profiles of three $B$. havanensis snails obtained from different localities of Cuba and B. peregrina, B. oligoza and $B$. orbignyi specimens from Brazil, Argentina and Uruguay. This enzyme produced a simple profile for $B$. havanensis showing two clear fragments which were very distinct from those obtained for the other species.

Analysis of the similarity among species - The similarity and distance analysis were performed using a taxon character matrix previously constructed using the 146 bands obtained with the six restriction enzymes used. The trees, obtained using Dice (Fig. 3) and Nei and Li coefficients (data not shown) and UPGMA cluster, show the genetic similarity and distance among the three species analyzed. Both trees exhibit similar topology. In Fig. 3 the degree of intraspecific similarity was approximately $51 \%$ for $B$. peregrina, $80 \%$ for $B$. oligoza and $69 \%$ for B. orbignyi. The average per-

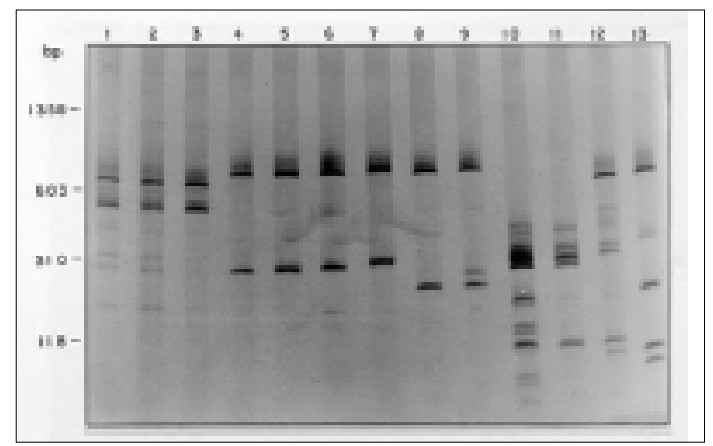

Fig. 2: silver stained polyacrylamide gels $6 \%$ showing the restriction fragment length polymorphism profiles obtained following the digestion of the rDNA internal transcribed spacer with MvaI. Lane 1: Biomphalaria havanensis from Canasi, Cuba; lane 2: B. havanensis from Santa Rita, Cuba; lane 3: B. havanensis from Guatao, Cuba; lane 4: B. peregrina from Bom Jesus da Penha, MG, Brazil; lane 5: B. peregrina from Alfenas, MG, Brasil; lane 6: B. peregrina Cholila, from Chubut Province, Argentina; lane 7: B. peregrina from Córdoba Province, Argentina; lane 8: B. oligoza from Eldorado do Sul, RS, Brazil; lane 9: B. oligoza from Córdoba Province, Argentina; lane 10: B. orbignyi from San Roque, Corrientes Province, Argentina; lane 11: B. orbignyi from La Carlota, Córdoba Province, Argentina; lane 12; B. orbignyi from Chamical, La Rioja Province, Argentina; lane 13: B. orbignyi from Patquia La Rioja Province, Argentina. Molecular size markers are shown on the left of each gel. centage of bands shared among all the possible pairs was $54 \%$ and is represented in the dendrogram (Fig. 3) by the dotted line (phenon line), which supports the presence of the three groups composed by $B$. peregrina, B. oligoza and $B$. orbignyi. In the distance tree obtained with Nei and $\mathrm{Li}$ coefficients two main clusters can be observed, one composed of $B$. peregrina and $B$. oligoza and another with $B$. orbignyi, supported by a high bootstrap value (100\%). We have found that in most cases, individuals from the same locality cluster together and that these branches were supported by bootstrap values over $70 \%$. These two main clades were also confirmed with a high statistical reliability when $\mathrm{NJ}$ cluster with $\mathrm{Nei}$ and $\mathrm{Li}$ distance (1979) and 1,000 pseudoreplications were used (data not shown). This tree reinforced the closer relation between $B$. peregrina and $B$. oligoza by a high bootstrap value (100\%). B. orbignyi cluster was also supported by a high bootstrap value $(100 \%)$.

\section{DISCUSSION}

The PCR and RFLP analysis of the internal transcribed spacer region, used here, has been useful in systematic studies of Biomphalaria snails to assist the classical morphological identification and to estimate genetic similarities among Biomphalaria species. Using this technique Caldeira et al. (1998) studied and confirmed the B. straminea complex proposed by Paraense (1988) based on morphological similarities among $B$. straminea, $B$. kuhniana and $B$. intermedia. Also using this methodology, Spatz et al. (1999) proposed the $B$. tenagophila complex due to the morphological and molecular similarities among B. t. tenagophila, $B$. t. guaibensis, and B. occidentalis. Caldeira et al. (2000) also using PCR-RFLP studied B. prona populations from Lake Valencia (Venezuela) and outside this lake, in which morphological differences had been previously described by Paraense et al. (1992). The first authors observed that in spite of these differences, similar profiles were generated for both populations. This molecular data provide support to this group suggested by Paraense et al. (1992) and revealed to be an useful tool for studying species with great phenotypic plasticity. After testing several enzymes, Vidigal et al. (2000) showed that specific separation between Brazilian populations of B. oligoza and B. peregrina became difficult due to the similarity of the profiles generated by this technique.

In the present study we selected $B$. oligoz $a$ and $B$. peregrina for a more extensive analysis using snail populations from Brazil, Argentina and Uruguay and several enzymes. B. orbignyi was included due to the high morphological similarities 


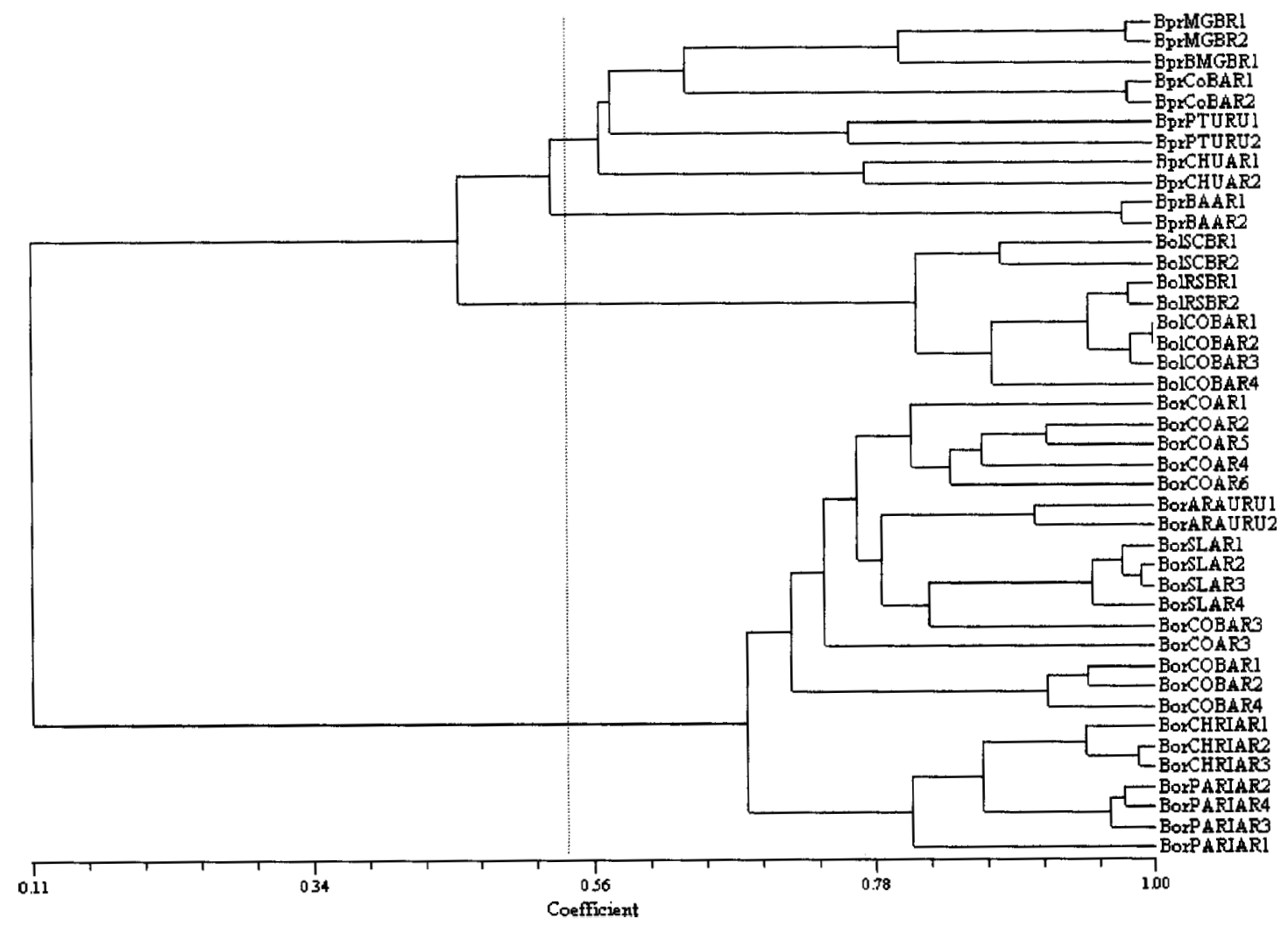

Fig. 3: unweighted pair group method analysis dendrogram using Dice similarity coefficient of Biomphalaria peregrina (Bpr), B. oligoza (Bol) and B. orbignyi (Bor) constructed using the polymerase chain reaction-restriction fragment length polymorphism profiles produced with all enzymes used. The numbers shown are indices of similarity. The letters refer to species and the localities from where the snails originate. Population names follow Table.

with B. peregrina. B. oligoza and B. peregrina exhibited very similar profiles with DdeI and RsaI (data not shown) and B. peregrina presented some polymorphism when AluI and HpaII were used, so they did not allow an easy identification of the species. However, when we used AluI, B. peregrina from Brazil presented one particular band, of approximately $200 \mathrm{bp}$, which allowed the separation of these specimens from $B$. oligoza, as previously showed by Vidigal et al. (2000). B. peregrina from Córdoba showed similar profiles to $B$. oligoza when the HpaII enzyme was used. These results mirror the high variability of $B$. peregrina and the high genetic similarity between these species. However, we can highlight that DdeI, AluI, HaeIII, HpaII and $R s a \mathrm{I}$ enzymes permitted the differentiation of $B$. peregrina and B. oligoza from B. orbignyi. The profiles obtained with all enzymes were used to construct phenetic trees using UPGMA that assume that all lineage have diverged on equal amounts. On the other hand, the NJ method, conceptually related to the traditional cluster analysis, does not make that assumption (Swofford et al. 1996). In the tree produced, using UPGMA and Dice coefficient, the phenon line supported (Fig. 3) the presence of three groups: $B$. peregrina, $B$. oligoz $a$ and $B$. orbignyi, but suggests that $B$. peregrina and $B$. oligoza are more closely related than $B$. peregrina and $B$. orbignyi. Trees constructed using UPGMA and $\mathrm{NJ}$ clusters and distance coefficients supported the formation of two groups: one that clustered $B$. peregrina and $B$. oligoza, also suggesting that these species are more closely related, and another group that clustered all B. orbignyi populations. These two main clades were supported by high bootstrap values obtained after 1,000 replications showed in the UPGMA distance tree and statistical reliability when NJ cluster was used (data not shown). Although by UPGMA three clusters can be distinguished (Fig. 3) and by NJ only two, both analysis stress the high genetic similarity between $B$. peregrina and B. oligoza.

However, by morphological characters, $B$. peregrina is more similar to $B$. orbignyi than to $B$. oligoza. Indeed, typical specimens of $B$. peregrina and $B$. oligoza are easily distinguishable by the 
number of prostatic diverticula (B. oligoza exhibit a small number, 1 to 6 , rarely $7, B$. peregrina 8 to 22) but sometimes, and due to the variability of this character, some specimens may present similar number of the prostatic diverticula ( $B$. oligoza maximum $7, B$. peregrina minimum 8 ) making their identification very difficult. When this occurs, $B$. peregrina can only be identified by the presence of prostatic diverticula covering the spermathecal body (Paraense 1966, 1975a). The differentiation of $B$. orbignyi from B. peregrina is based on differences in male genitalia. The wider portion of the distal segment of the vas deferens is narrower than the middle portion of the penial sheath in B. peregrina and about the same width in B. orbignyi (Paraense 1975b).

Moritz and Hillis (1996) mentioned that the development of molecular systematic has not resulted in widespread refutation of data produced by morphological analysis. These authors reported that, in general, studies that incorporate both molecular and morphological data will provide much better descriptions and interpretation of the biological diversity of the organisms studied. Disagreement between morphology and molecular results suggests the complex relation among $B$. peregrina, $B$. orbignyi and $B$. oligoza. So, based on our results, we have proposed that phylogenetic relationships among these similar species should be clarified later by sequence analysis of the ITS region.

In a previous molecular study, $B$. peregrina showed more intraspecific variation when compared with $B$. intermedia, B. kuhniana and $B$. straminea (Caldeira et al. 1998). The high intraspecific morphological and genetic variability observed here for $B$. peregrina may be attributed to its dispersion and wide distribution in the neotropical region, contrasting with low levels of variability and limited geographical distribution of B. oligoza and B. orbignyi species.

Additionally, the MvaI enzyme was used to separate B. peregrina, B. oligoza and B. orbignyi from $B$. havanensis obtained from different localities of Cuba (Fig. 2), which has been reported as very similar to B. peregrina (Paraense 1975b, Yong $\&$ Perera 1989, Yong et al. 1991, 1995). The last species is present in regions where B. havanensis and $B$. orbignyi were also reported (Yong et al. 1989). Thus, MvaI enzyme can be used to elucidate and confirm the identification of these snails when the morphological diagnosis is not sufficiently clear.

\section{ACKNOWLEDGEMENTS}

To Dr Wladimir Lobato Paraense, Departamento de Malacologia, Instituto Oswaldo Cruz, Fiocruz, for the assistance on the morphological identification of the snails. To Dr Gloria Perera Puga and Mary Yong, Instituto Pedro Kouri, Cuba who gave us the Biomphalaria havanensis snails. To Roberta Lima Caldeira for the assistance in the discussion of this work.

\section{REFERENCES}

Caldeira RL, Vidigal THDA, Paulinelli ST, Simpson AJG, Carvalho OS 1998. Molecular identification of similar species of the genus Biomphalaria (Mollusca: Planorbidae) determined by a PCR-RFLP. Mem Inst Oswaldo Cruz 93: 219-225.

Caldeira RL, Vidigal THDA, Matinella L, Simpson AJG, Carvalho OS 2000. Identification of planorbids from Venezuela by polymerase chain reaction amplification and restriction fragment length polymorphism (PCR-RFLP). Mem Inst Oswaldo Cruz 95: 171-177.

Carvalho OS, Nunes IM, Caldeira RL 1998. First report of Biomphalaria glabrata in the State of Rio Grande do Sul, Brazil. Mem Inst Oswaldo Cruz 93: 39-40.

Corrêa LR, Paraense WL 1971. Susceptibility of Biomphalaria amazonica to infection with two strains of Schistosoma mansoni. Rev Inst Med Trop São Paulo 13: 387-390.

Deslandes N 1951. Técnica de dissecação e exame de planorbídeos. Rev Serv Espec Saúde Púb 4: 371-382.

Dice LR 1945. Measures of the amount of ecological association between species. Ecology 26: 297-302.

Felsenstein J 1985. Confidence limits on phylogenies: an approach using the bootstrap. Evolution 39: 783791.

Graeff-Teixeira C, Dos Anjos CB, Oliveira VC, Velloso CFP, Fonseca MBS, Valar C, Moraes C, Garrido CT, Amaral RS 1999. Identification of a transmission focus of Schistosoma mansoni in the southernmost Brazilian State, Rio Grande do Sul. Mem Inst Oswaldo Cruz 94: 9-10.

Hillis DM, Huelsenbeck JP 1992. Signal, noise and reliability in molecular phylogenetics analyses. Heredity 83: 189-195.

Hope M, McManus DP 1994. Genetic variations in geographically isolated populations and subspecies of Oncomelania hupensis determined by a PCR-based RFLP method. Acta Trop 57: 75-82.

Kane RA, Rollinson D 1994. Repetitive sequences in the ribosomal DNA internal transcribed spacer of Schistosoma haematobium, Schistosoma intercalatum and Schistosoma mattheei. Mol Bioch Parasitol 63: 153-156.

Malek EA 1985. Snail Hosts of Schistosomiasis and other Snail-transmitted Diseases in Tropical America: a Manual, OPAS, WHO, Washington, USA, $325 \mathrm{pp}$.

Moritz C, Hillis DM 1996. Molecular systematic: context and controversies. In DM Hillis, C Mortiz, BK Mable (eds), Molecular Systematics, 2nd ed., Sunderland, Massachusetts, p. 1-13.

Nei M, Li WH 1979. Mathematical model for studying genetic variation in terms of restriction endonucleases. Proc Natl Acad Sci USA 76: 5269-5273.

Paraense WL 1966. The synonymy and distribution of 
Biomphalaria peregrina in the Neotropical region. Rev Bras Biol 26: 269-296.

Paraense WL 1970. Planorbídeos hospedeiros intermediários do Schistosoma mansoni. In AS da Cunha, Esquistosomose Manoni, Universidade de São Paulo, Brasil, p. 13-30.

Paraense WL 1974. Biomphalaria oligoza N.N. for Tropicobis philippianus (Dunker) sensu Lucena. Rev Brasil Biol 34: 379-386.

Paraense WL 1975a. Estado atual da sistemática dos planorbídeos brasileiros. Arq Mus Nac Rio de Janeiro 55: 105-128.

Paraense WL 1975b. Biomphalaria orbignyi sp. n. from Argentina (Gastropoda: Basommatophora: Planorbidae). Rev Brasil Biol 35: 211-222.

Paraense WL 1976. A natural population of Helisoma duryi in Brazil. Malacology 15: 360-376.

Paraense WL 1987. Probable extension of schistosomiasis mansoni to southermost Brazil. Mem Inst Oswaldo Cruz 82: 577.

Paraense WL 1988. Biomphalaria kuhniana (Clessin, 1883), planorbid mollusc from South America. Mem Inst Oswaldo Cruz, 83: 1-12.

Paraense WL, Corrêa LR 1973. Susceptibility of Biomphalaria peregrina from Brazil and Ecuador to two strains of Schistosoma mansoni. Rev Inst Med Trop São Paulo 15: 127-130.

Paraense WL, Deslandes N 1957. Observations sur Taphius maya. J Conchyliol 97: 49-58.

Paraense WL, Deslandes N 1958a. Observations on Taphius havanensis (Pulmonata, Planorbidae). Rev Brasil Biol 18: 87-91.

Paraense WL, Deslandes N 1958b. Another Brazilian species of Taphius (Pulmonata, Planorbidae). Rev Brasil Biol 18: 209-217.

Paraense WL, Pointier JP, Delay B, Pernot AF, Incani RN, Balzan C, Chrosciechowski P 1992. Biomphalaria prona (Gastropoda: Planorbidae): a morphological and biochemical study. Mem Inst Oswaldo Cruz 87: 171-179.

Richards CS 1963. Infectivity of Schistosoma mansoni for Puerto Rico mollusks, including a new potential intermediate host. Am J Trop Med Hyg 12: 26-33.

Rohlf FJ 1992. NTSYS numerical taxonomy and multivariate analysis system, Version 1.70, Exeter Software, New York.

Saitou N, Nei M 1987. The neighbor-joining method: a new method for reconstructing phylogenetic trees. Mol Biol Evol 4: 406-426.

Sneath PHA Sokal RR 1962. Numerical taxonomy. Nature 193: 855-860.

Spatz L, Vidigal THDA, Caldeira RL, Dias Neto E,
González Cappa SM, Carvalho OS 1999. Study of Biomphalaria tenagophila tenagophila, B. $t$. guaibensis and $B$. occidentalis by polymerase chain reaction amplification and restriction enzyme digestion of the ribosomal RNA intergenic spacer regions. J Moll Stud 65: 143-149.

Stothard JR, Hughes S, Rollinson D 1996. Variation within the internal transcribed spacer (ITS) of ribossomal DNA genes of intermediate snail hosts within the genus Bulinus (Gastropoda: Planorbidae). Acta Trop 61: 19-29.

Stothard JR, Rollinson D 1997. Molecular characterization of Bulinus globosus and B. nasutus in Zanzibar, and an investigation of their roles in the epidemiology of Schistosoma haematobium. Trans R Soc Trop Med Hyg 91: 353-357.

Studier JA, Keppler KJ 1988. A note on the neighbourjoining algorithm of Saitou and Nei. Mol Biol Evol 5: 729-731.

Swofford DL, Olsen GJ, Waddell PJ, Hillis DM 1996. Phylogenetic inference. In DM Hillis, C Moritz, BK Mable (eds), Molecular Systematics, Sinauer Associates Inc., Massachusets, p. 486-493.

Van de Peer Y, De Wachter R 1994. TRECON for Windows: a software package for the construction and drawing of evolutionaty trees for the Microsoft Windows environment. Comput Applic Biosci 10: 569570.

Vidigal THDA, Spatz L, Nunes ND, Simpson AJG, Carvalho OS, Dias Neto E 1998. Biomphalaria spp.: identification of the intermediate snail hosts of Schistosoma mansoni by polymerase chain reaction amplification and restriction enzyme digestion of the ribosomal RNA gene intergenic spacer. Exp Parasitol 89: 180-187.

Vidigal THDA, Caldeira RL, Simpson AJG, Carvalho OS 2000. Further studies on the molecular systematics of Biomphalaria snails from Brazil. Mem Inst Oswaldo Cruz 95: 57-66.

Yong M, Perera G 1989. First record of Biomphalaria orbignyi in Cuba. Walkerana 3: 211-215.

Yong M, Perera G, Gutierrez A 1995. Biomphalaria havanensis y Biomphalaria orbignyi (Mollusca: Planorbidae): dos especies en sinonimia? Rev Cubana Med Trop 47: 209-210.

Yong M, Perera G, Lopes JRF 1991. Caracterizacion de Biomphalaria orbignyi Paraense, 1974, molusco de importância médico-epidemiológico recientemente reportado para Cuba. Rev Cubana de Med Trop 43: 21-25.

Yong M, Perera G, Pointier JP 1989. Presence of Biomphalaria peregrina in Hanabanilla, Cuba. $J$ Med App Malacol 1: 183-187. 